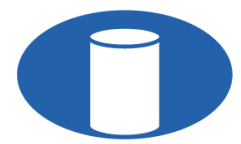

IBRACON Structures and Materials Journal

Revista IBRACON de Estruturas e Materiais

ORIGINAL ARTICLE

\title{
Probabilistic analysis of slab-column connections subjected to punching shear according to the ABNT NBR 6118 (2014) recommendations considering the model error measure
}

\author{
Análise probabilística de ligações laje-pilar submetidas à punção segundo as \\ recomendações da ABNT NBR 6118 (2014) considerando a medida do erro de \\ modelo
}

Náyra Louise Alonso Marque ${ }^{\mathrm{a}}$ (1)

Caio Gorla Nogueira ${ }^{\text {a }}$ (D)

${ }^{a}$ Universidade Estadual Paulista - UNESP, Departamento de Engenharia Civil e Ambiental, Bauru, SP, Brasil

Received 12 November 2020 Accepted 15 March 2021

\begin{abstract}
Reinforced concrete flat slabs are structural systems in which slabs are directly supported by columns, without the use of beams. A structural phenomenon that deserves attention in these systems is the punching shear, characterized by the occurrence of shear stresses close to the slab-column interface, which can produce fragile rupture in those regions. This study presents some results of reliability index $\beta$ obtained for slab-column connections based on FORM, according to the Brazilian standard's model, considering the model error. The critical contours $C$ and $C^{\prime}$ without shear reinforcement are analyzed. The results showed that failure in the $C$ contour is very unlikely, while the probabilities of rupture in the $C^{\prime}$ contour when considering the influence of the model error are greater than the target values recommended in the literature for the ULS.

Keywords: slab-column connection, punching shear, reliability, reinforced concrete.
\end{abstract}

Resumo: Lajes lisas de concreto armado são sistemas estruturais compostos por lajes diretamente apoiadas em pilares, sem o uso de vigas. Um fenômeno estrutural que merece atenção nesses sistemas é a punção, caracterizada pela ocorrência de tensões de cisalhamento nas proximidades da interface laje-pilar, que podem produzir ruptura frágil nessas regiões. Este estudo apresenta resultados do índice de confiabilidade $\beta$ obtidos para ligações laje-pilar a partir de análises de confiabilidade utilizando o FORM, segundo o modelo da norma brasileira, considerando o erro de modelo. Os contornos críticos $C$ e $C^{\prime}$ sem armadura de punção são analisados. Os resultados mostraram que a falha no contorno $C$ é muito improvável, enquanto que as probabilidades de ruptura no contorno $C^{\prime}$ 'quando se considera a influência do erro de modelo são maiores que valores alvo recomendados na literatura para o ELU.

Palavras-chave: ligação laje-pilar, punção, confiabilidade, concreto armado.

How to cite: N. L. A. Marque and C. G. Nogueira, "Probabilistic analysis of slab-column connections subjected to punching shear according to the ABNT NBR 6118 (2014) recommendations considering the model error measure," Rev. IBRACON Estrut. Mater., vol. 14, no. 6, e14609, 2021, https://doi.org/10.1590/S1983-41952021000600009

\section{INTRODUCTION}

Flat slab systems have been used frequently in multi-storey buildings replacing conventional systems defined by slabs, beams and columns. The main characteristic of flat slabs is the absence of beams and the load direct transference from slabs to columns. Regarding the conventional mentioned system, the flat slabs have some advantages: agility to execute the framework of the slab panels, reduction in the interference between the structural elements and the hydrosanitary installations; better standardization of the shoring; reduction in the total height of the building; less concrete 
waste [1]. However, there are some aspects on the structural behavior of these systems that must be carefully analyzed, which are: global stability of the building and the punching shear phenomenon in the slab-column connection. The absence of rigid frames (no beams in the structural system) may lead to excessive transversal displacements overcoming the allowable values recommended by the normative codes. In such cases, different bracing systems must be combined to the columns to provide the global stability of the building.

Punching shear is an Ultimate Limit State - ULS [2] caused by the stress concentration in specific regions of the slab around the column. The column tends to penetrate the slab leading to a brittle failure mode as depicted in Figure $1 \mathrm{~b}$. When the rupture is imminent, a punching cone can be seen around the column due to the principal tensile stresses produced by the acting shear stresses in the slab-column connection. In a building floor, the position of the column (central, border or edge) acts directly on the punching shear phenomenon because the boundary conditions affect the stress distribution in the slabs (Figure 1a).

The stress distribution in the slab at the proximities of the column has a complex behavior, especially because, besides the shear stresses, there are also the presence of normal stresses come from the negative bending moments acting at the top of the slab. In this way, there are several mechanisms of energy dissipation produced by the stress transference process at the slab-column connections, which makes difficult to develop accurate and simple analytical models to predict the punching shear resistance of those connections. In general, the normative codes present analytical models to estimate the punching shear resistance of the slab-column connection. These models can also be used to design shear reinforcement disposed around the slab-column interface, in order to prevent the formation of the punching cone. The theoretical bases of these normative predicting models are the Surface Control Method, which compares the acting and resistant shear stresses in particular regions near the slab-column interface [4]. Each standard code differs from each other by the definition of these particular regions, in which the safety requirements are evaluated.
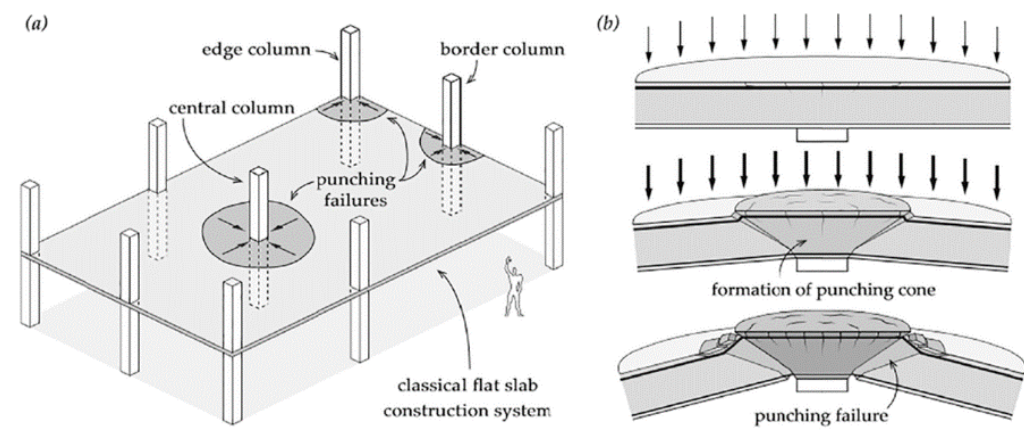

Figure 1. (a) Slab regions submitted to punching shear for the three different column positions; (b) first cracks formation; punching cone at the imminence of rupture for central columns; punching shear failure at the slab-column connection [3].

Several national [5]-[18] and international [19]-[28] researches have been performed to better understand the punching shear phenomenon, since the first cracks initiation until failure, with or without shear reinforcement. The combination of these two areas, which are the experimental study of the phenomenon and the application of the normative/theoretical analytical models to predict bearing capacity is a relevant effort in order to estimate the precision and uncertainties associated to those models [6], [29]-[32]. Regarding the uncertainties field, the design parameters of the slab-column connections, which are concrete and steel strength, slab thickness and column cross section dimensions can be also considered as random quantities because of the inherent variability, lack of knowledge and data about them and even human errors that can occur in the execution phase. Therefore, a well-known fact must be remembered here: if there are uncertainties on the input data to predict punching shear behavior, there will be uncertainty on the final response of such process, which is the punching bearing capacity of a slab-column connection.

In this scenario, the Reliability Theory has been adopted to estimate probabilities of failure for ULS in different types of slab-columns connections, considering parameters uncertainties. Reliability analysis estimates on the adequacy of normative design procedures, including the accuracy of the prediction models and the recommended set of partial design factors [33], [34]. In such regard, model errors are also defined as a good indicator of general quality and accuracy of the analytical prediction models. These errors are constructed by comparison between experimental and predicted analytical values of ultimate load, for example. This is a procedure to incorporate the model uncertainty in the reliability analysis and will be better illustrated later. 
In this context, this article presents a set of reliability analyzes for slab-column connections applied to central, border and edge columns without shear reinforcement, considering the ABNT NBR 6118 [35] theoretical prediction model. The model uncertainty was obtained for each type of column and taken into account in the reliability analyzes carried out by FORM (First Order Reliability Method).

\section{ABNT NBR 6118 PREDICTION MODEL FOR PUNCHING SHEAR}

According to the Brazilian code ABNT NBR 6118 [35], some special regions around de slab-column connection must be verified in order to guarantee the safety of the system. These regions are called critical perimeters and are defined for each type of column (central, border and edge). In cases without shear reinforcement, there are two regions to verify: interface of the slab and column (critical perimeter $C$ ); a region around the column defined by $2 d$ distance from the interface slab-column (critical perimeter $C^{\prime}$ ). Figure 2 illustrates the critical perimeters $C$ and $C^{\prime}$ for each type of analyzed column, in which $d$ is the slab serviceable thickness.
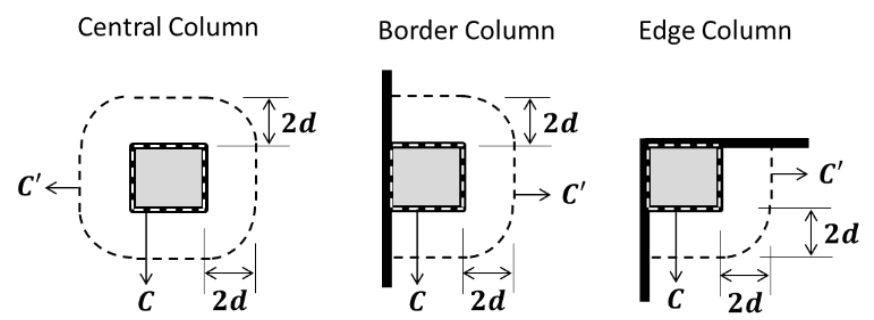

Figure 2. Critical perimeters $C$ and $C$ ' defined for central, border and edge columns according ABNT NBR 6118 [35].

For the critical perimeters $C$ and $C^{\prime}$, the verifications refer to the safety of the concrete diagonal compression $\tau_{R d 2}$ along the slab thickness and the concrete diagonal tensile $\tau_{R d 1}$, respectively. The analytical models to assess the slabcolumn connection resistance for the two cited critical perimeters are given by:

$$
\begin{aligned}
& \tau_{R d 2}=0,27\left(1-\frac{f_{c k}}{250}\right) f_{c d} \\
& \tau_{R d 1}=0,13\left(1+\sqrt{\frac{20}{d}}\right)\left(100 \rho f_{c k}\right)^{\frac{1}{3}}
\end{aligned}
$$

In which: $f_{c k}$ is the characteristic concrete compressive strength; $f_{c d}$ is the design concrete compressive strength given by $f_{c k} / 1,4 ; d$ is the slab serviceable thickness; $\rho$ corresponds to the bending reinforcement geometric ratio of the slab given by $\sqrt{\rho_{x} \rho_{y}} ; \rho_{x}$ and $\rho_{y}$ are the bending reinforcement geometric ratio of the slab at the orthogonal directions $x$ and $y$.

The acting shear stress for central and border columns are given by Equation 3, in which the concentrated load $(F)$ applied by the columns at the slab, as well as the presence of the two bending moments $\left(\mathrm{M}_{1}\right.$ e $\left.\mathrm{M}_{2}\right)$ are considered. Regarding the edge columns and the existence of two free borders, the acting shear stress must be addressed for each border separately, considering the bending moment which is perpendicular to the adopted free border [35]. The ABNT NBR 6118 [35] make some recommendations about when to consider or not the presence of bending moment in central, border and even edge columns. However, such recommendations will be not discussed in this article, but they can be found at the cited code and [4]-[6].

$$
\tau_{s d}=\frac{F}{u d}+\frac{K_{1} M_{1}}{W_{p 1} d}+\frac{K_{2} M_{2}}{W_{p 2} d}
$$


In which: $\tau_{s d}$ is acting shear stress; $u$ is the critical perimeter depending on the type of the column and the respective analyzed region; $K_{l}$ and $K_{2}$ are the coefficients that represent the bending moment portion transferred to the column by shear. The resultant values for $K_{l}$ and $K_{2}$ can be found in Lima [4]. $W_{p 1}$ e $W_{p 2}$ are the plastic resistance modulus of the critical perimeter, whose equations for rectangular central column can be found in ABNT NBR 6118 [35] and in Melges [6] for rectangular border and edge columns. The Brazilian code adopts, for central columns, a surface $2 d$ from the interface slab-column (Figure 2) as the critical contour $C^{\prime}$ ' with perimeter $u=2\left(C_{1}+C_{2}\right)+4 \pi d$. For instance, $C_{1}$ and $C_{2}$ are, respectively, the column cross section dimensions parallel and orthogonal to the considered eccentricity. On the other hand, for border and edge columns, the critical perimeter of $C^{\prime}$ surface can be evaluated with a reduction, as depicted in Figure 3.
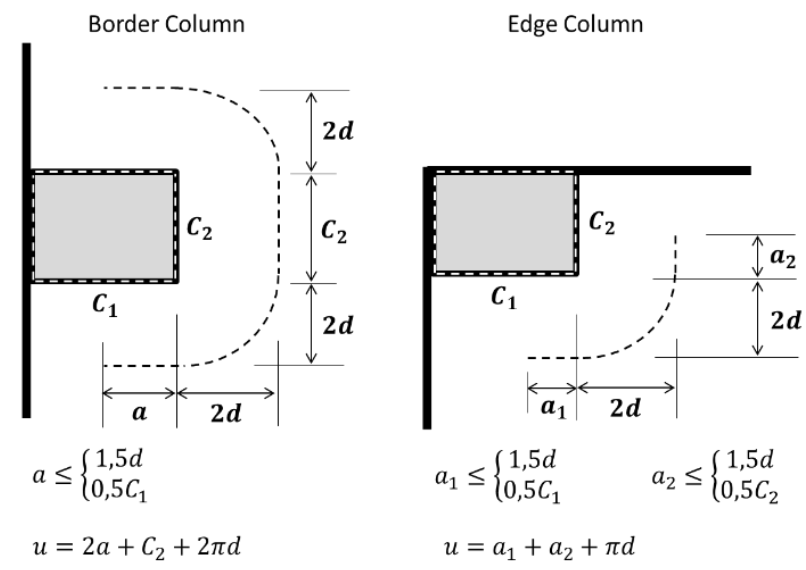

Figure 3. Reduced critical perimeters of $C^{\prime}$ ' contour for border and edge columns.

The acting shear stress (Equation 3) is still valid for cases with just one bending moment or even only the normal force. In such cases, the referred portions must be zero for the assessing of $\tau_{s d}$.

\section{MODEL ERROR UNCERTAINTY QUANTIFICATION}

A model error variable was defined to consider the uncertainty of the ABNT NBR 6118 [35] punching shear resistance prediction model. The model error $\left(E_{m}\right)$, for each type of column, is given by the ratio between experimental rupture load $\left(F_{\text {exp }}\right)$ and normative theoretical prediction $\left(F_{\text {teo }}\right)$ as:

$E_{m}=\frac{F_{\text {exp }}}{F_{\text {teo }}}$

The normative theoretical prediction force was obtained by Equation (3) for critical perimeter $C^{\prime}$. In all the analyzed experimental results in literature [1], [5], [7], [9]-[18], [19]-[28], [36]-[42], no punching shear failure in critical contour $C$ was observed, but only near at the critical perimeter $C^{\prime}$. Therefore, the model error refers only to the $C^{\prime}$. Another aspect worth to mention is about the implicit safety factor $(1,4)$ in the Equation 2 at the coefficient 0,13 . According to Carvalho et al. [1], the Brazilian code adopts the same model as the Eurocode 2 [43], in which the value of 0,13 is reached by $0,18 / 1,4$. Thus, in the reliability analyzes, the new coefficient that will be used is 0,18 instead 0,13 in order to eliminate such safety factor. Regarding the concrete compressive strength, the used value to assess the theoretical prediction force was always the same value that was considered at the experimental results, which is $f_{c}$ instead $f_{c k}$.

The model error was calculated for each type of column from comparisons between experimental and theoretical rupture forces (Equation 4) considering: 126, 74 and 13 experimental results for central, border and edge column, respectively [1], [5], [7], [9]-[18], [19]-[28], [36]-[42]. Only experimental slab-column connections failed by punching shear were considered in the model error calibration. Flexural failures were all rejected. The experimental data were not separated in different sub-sets with specific ranges of slab thickness or longitudinal reinforcement rates; they are 
treated as a single set of data. In order to choose the best probability distribution for each model error, the KolmogorovSmirnov test was performed for normal and lognormal distributions with significance level of $5 \%$. The model error uncertainty quantification results are shown in Table 1 . The significant differences among the mean value and the respective coefficients of variation for the three slab-column connections could be associated to the different stress distribution around the columns and to the differences from the longitudinal reinforcement rates. All the consulted data used to perform the error model quantification are presented in Tables A1, A2 and A3 in the Appendix. It is also shown in the Appendix the identified tendencies of the error model according to some design parameters of the slab-column connections.

In order to make some comparisons, the model error statistics was evaluated considering more than 120 experimental results for slab-central column connections and the ABNT NBR 6118 [35] punching shear resistance prediction model without shear reinforcement [29]. The related results shown 0,96 mean value and coefficient of variation equal to $14,1 \%$.

Table 1. Model error random variable for critical perimeter $C^{\prime}$.

\begin{tabular}{ccccc}
\hline & Mean Value & Standard Deviation & Coefficient of Variation & $\begin{array}{c}\text { Probability } \\
\text { Distribution }\end{array}$ \\
\hline Central Column & 0,962 & 0,197 & $20,5 \%$ & Normal \\
\hline Border Column & 1,151 & 0,246 & $21,4 \%$ & Lognormal \\
\hline Edge Column & 1,363 & 0,404 & $29,7 \%$ & Lognormal \\
\hline
\end{tabular}

\section{STRUCTURAL RELIABILITY APPLIED TO PUNCHING SHEAR ANALYSIS}

The scientific and technical demand for uncertainty quantification has grown significantly in the last decade. The following basic premises support such demand: i) the growing perception that everything is surrounded by uncertainties; ii) if there are uncertainties in the input, there will be uncertainties in the output [44]. Hence, there will always be a probability that designed engineering system does not achieve the defined specifications of operation, generating undesirable engineering scenarios.

The concept of probability of failure must be understood as a propensity measure (subjective or Bayesian definition) that a component and/or system is unable to meet the design requirements along a specific lifetime, even when the recommendations and operation conditions are respected [45]. The Reliability Theory can be an interesting approach to estimate those probabilities of limit state violation for isolated components and/or structural systems.

In this article, the analyzed failure modes are due to the ruin (ULS) of the slab-column connection by punching shear in pre-defined regions according to ABNT NBR 6118 [35]. The Limit State Functions (LSF) of the failure modes are defined in terms of safety margin as $G=R-S$, in which $R$ and $S$ stands for the resistance and solicitation of the slab-column connection and are represented by shear stresses at specific regions.

The failure punching shear event occurs when $G=R-S<0$ condition is achieved; otherwise the safety/survival event of the slab-column connection is represented by $G>0$. When $G=0$, the event $R=S$ is defined meaning the imminence of the failure. Therefore, the reliability analyzes aim to estimate de probability of failure, which represents the event $G \leq 0$.

The reliability problem is solved in the Standard Gaussian space $Y$. In this space, the random variables are dimensionless with mean value zero and standard deviation equal to 1 . The condition $G=0$ in the $Y$ space refers to the boundary of failure and safety domain. The shortest distance between the origin of the $Y$ space and the limit state equation $G=0$ represents the reliability index $\beta$ [46]. The point located at the surface $G=0$ is called design point $Y^{*}$ and provides the probability of failure $P_{f}$ for that failure mode. Therefore, the reliability index can also be interpreted as a safety measure because the higher $\beta$, the lower probability of failure. For instance: for $\beta=0 \rightarrow P_{f}=0,50 ; \beta=1,645 \rightarrow P_{f}=0,05 ; \beta=3,8 \rightarrow P_{f}=5 \times 10^{-5} ; \beta=5,0 \rightarrow P_{f}=2,9 \times 10^{-7}$. The probability of failure is given by $P[G \leq 0]=\Phi(-\beta)$, in which $\Phi($.$) represents the cumulative density function of probabilities$ at the Standard Gaussian space $Y$.

It is important, after the reliability index and probability of failure assessment, to compare the obtained values to target references. The punching shear failure is an occurrence of ULS, with moderate to high failure consequences [47], according to total and building construction costs ratio. Table 2 shows minimum values for $\beta$ and $P_{f}$ in ULS recommended by the European code EN 1990:2002 [48], for three risk classes, defined by the consequences of failure with 50 years return period [49].

For effect of comparison, in this article, it was adopted $\beta_{\min }=3,8$ for ULS with moderate consequences of failure. 
Table 2. Minimum reliability index recommended by EN 1990:2002 for a 50-year return period [48].

\begin{tabular}{ccc}
\hline \multicolumn{4}{c}{ Failure Consequences } \\
\hline Low & Moderate & High \\
\hline$\beta_{\text {min }}=3,3 \quad P_{f} \approx 5 \times 10^{-4}$ & $\beta_{\text {min }}=3,8 \quad P_{f} \approx 5 \times 10^{-5}$ & $\beta_{\text {min }}=4,3 \quad P_{f} \approx 10^{-5}$ \\
\hline
\end{tabular}

The reliability problem is formulated from the following information: limit state functions definition for each critical perimeter of the all three columns; table with the all the random variables including the model error. The Figure 4 shows two flowcharts illustrating the performed reliability analyzes. They are explained below.

There are two sets of analyzes in which the legend C, B, E means central, border and edge column, respectively.
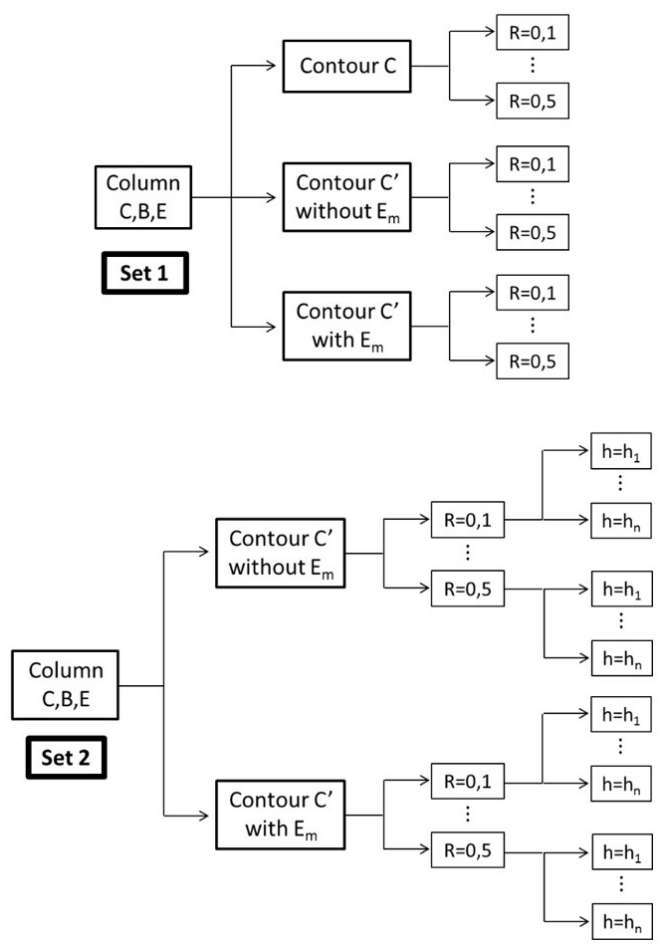

Figure 4. Flowchart of the performed reliability analyzes.

Regarding the set 1 , three sub-sets for each type of column were performed: at sub-set 1 , the failure mode is given by the critical perimeter $C$ without the model error; at sub-sets 2 and 3, the failure mode is given by the critical perimeter $C$, without and with the model error, respectively. For all these performed analyzes, the mean value of the slab thickness is kept constant, but the loading ratio $R$ varies between 0,1 and 0,5 with increment of 0,1 . The loading ration $R$ is defined by the ratio between the live load $q$ and the total load $g+q$ (dead load plus living load), given by $R=q /(g+q)$.

The second set of analyzes considers the same three types of columns, but only for the sub-sets 2 and 3 , which are failure mode given by the critical perimeter $C$ ' without and with the model error, respectively. The main difference between the sub-sets 1 and 2 is that the mean slab thickness, at sub-set 2, varies with an increasement of $1 \mathrm{~cm}$ in a prefixed range, but keeping the coefficient of variation constant. For each value of the loading ratio $R(0,1$ to 0,5$)$, this slab thickness variation is performed.

The analyzed slab-column connections (central, border and edge column) in this paper belong to a flat slab building studied and presented by Lima [4]. The rectangular flat slab was designed with thickness $=18 \mathrm{~cm}$; concrete cover $=2 \mathrm{~cm}$; reinforcement bars at the two orthogonal directions according with the parallel borders of the slab $=12,5 \mathrm{~mm}$ diameter; $\mathrm{f}_{\mathrm{ck}}=30 \mathrm{MPa}$. The distance between two parallel longitudinal bars varies with the type of column and will be mentioned later for each analyzed case. 
The limit state functions for each described failure mode were defined by the safety margin written as: $G(\boldsymbol{X})=R(\boldsymbol{X})-S(\boldsymbol{X})$, in which $\boldsymbol{X}$ is the random variable vector. For each critical perimeter, the limit state functions of the central and border columns are listed below. In case of the edge column, it is only necessary to eliminate the last term of the acting shear stress in all the limit state functions.

- Critical Perimeter $C$ :

$R(\boldsymbol{X})=0,27\left(1-\frac{f_{c}}{250}\right) f_{c}$

- Critical Perimeter C' without Model Error:

$R(X)=0,18\left(1+\sqrt{\frac{20}{d}}\right)\left(100 \rho f_{c}\right)^{\frac{1}{3}}$

- Critical Perimeter $C^{\prime}$ with Model Error:

$R(\boldsymbol{X})=E_{m} \times\left[0,18\left(1+\sqrt{\frac{20}{d}}\right)\left(100 \rho f_{c}\right)^{\frac{1}{3}}\right]$

The $S(X)$ in all cases is given by:

$S(\boldsymbol{X})=\left(\frac{F_{g}+F_{q}}{u d}+\frac{K_{1}\left(M_{g, 1}+M_{q, 1}\right)}{W_{p 1} d}+\frac{K_{2}\left(M_{g, 2}+M_{q, 2}\right)}{W_{p 2} d}\right) 10$

In which: $F_{g}$ and $F_{q}$ in $\mathrm{kN}$ are, respectively, the dead and live load; $M_{g, 1}, M_{q, 1}, M_{g, 2}$ and $M_{q, 2}$ in $\mathrm{kNcm}$ are, respectively, the dead and live bending moment at directions 1 and 2. In the reliability analyzes, no safety factor was used. The constant number 10 multiplying $S(\boldsymbol{X})$ was adopted to guarantee the MPa unity as the same for $R(\boldsymbol{X})$. The acting bending moments were calculated from the product between the corresponding portion of the load (dead or live) and the respective eccentricity. The values of eccentricities were adopted, for each direction and each column, according with Lima [4].

Table 3. Adopted random variables: general presentation.

\begin{tabular}{cccc}
\hline Random Variable & Symbol & $\begin{array}{c}\text { Coefficient of } \\
\text { Variation }\end{array}$ & Probability Distribution \\
\hline Concrete compressive strength [50] & $\mathrm{f}_{\mathrm{c}}(\mathrm{MPa})$ & $14 \%$ & Lognormal \\
\hline Slab thickness [51] & $\mathrm{h}(\mathrm{cm})$ & $4 \%$ & Normal \\
\hline $\begin{array}{c}\text { Distance between the geometrical center of the upper } \\
\text { negative reinforcement and the compressed concrete } \\
\text { bottom face [52] }\end{array}$ & $\mathrm{d}^{\prime}(\mathrm{cm})$ & $12,5 \%$ & Normal \\
\hline $\begin{array}{c}\text { Column dimension parallel to the load eccentricity [52] } \\
\text { Column dimension orthogonal to the load eccentricity } \\
\text { [52] }\end{array}$ & $\mathrm{C}_{1}(\mathrm{~cm})$ & $4 \%$ & Normal \\
\hline $\mathrm{C}_{2}(\mathrm{~cm})$ & $4 \%$ & Normal \\
\hline Total load eccentricities [52] & $\mathrm{e}_{\mathrm{x}}, \mathrm{e}_{\mathrm{y}}(\mathrm{cm})$ & $10 \%$ & Normal \\
\hline Dead load [53] & $\mathrm{Fg}_{\mathrm{g}}(\mathrm{kN})$ & $10 \%$ & Normal \\
\hline Live load [53] & $\mathrm{F}_{\mathrm{q}}(\mathrm{kN})$ & $25 \%$ & Gumbel max type I \\
\hline
\end{tabular}


Table 3 presents all the random variables of the reliability problem. The serviceable thickness of the slab $d$ is given by $h-d^{\prime}$. The coefficient of variation and probability density function for all the random variables were defined from the literature information, except the statistics of the model error. No correlation between pair of random variables was adopted.

Table 4 gathers the random variables values for the three slab-column connections. The used legend in the table stands for: R.V. is the symbol of the random variable according to the definition in Table $3 ; \mu$ and $\sigma$ correspond, respectively, to the mean value and the standard deviation for each random variable.

Table 4. Values of the Random Variables for the three types of columns: set 1.

\begin{tabular}{|c|c|c|c|c|c|c|}
\hline \multirow{2}{*}{ R.V. } & \multicolumn{2}{|c|}{ Central Column } & \multicolumn{2}{|c|}{ Border Column } & \multicolumn{2}{|c|}{ Edge Column } \\
\hline & $\mu$ & $\sigma$ & $\mu$ & $\sigma$ & $\mu$ & $\sigma$ \\
\hline $\mathrm{f}_{\mathrm{c}}(\mathrm{MPa})$ & 38,98 & 5,46 & 38,98 & 5,46 & 38,98 & 5,46 \\
\hline $\mathrm{h}(\mathrm{cm})$ & 18,00 & 0,72 & 18,00 & 0,72 & 18,00 & 0,72 \\
\hline d' (cm) & 3,25 & 0,41 & 3,25 & 0,41 & 3,25 & 0,41 \\
\hline $\mathrm{C}_{1}(\mathrm{~cm})$ & 30,00 & 1,20 & 40,00 & 1,60 & 30,00 & 1,20 \\
\hline $\mathrm{C}_{2}(\mathrm{~cm})$ & 40,00 & 1,60 & 30,00 & 1,20 & 30,00 & 1,20 \\
\hline$e_{x}(\mathrm{~cm})$ & 3,98 & 0,40 & 48,00 & 4,80 & 56,31 & 5,63 \\
\hline $\mathrm{e}_{\mathrm{y}}(\mathrm{cm})$ & 9,12 & 0,91 & 11,52 & 1,15 & - & - \\
\hline \multirow{5}{*}{$\mathrm{F}_{\mathrm{g}}(\mathrm{kN})$} & $\mathrm{R}=0,1 \rightarrow 311,18$ & 31,12 & $\mathrm{R}=0,1 \rightarrow 168,08$ & 16,81 & $\mathrm{R}=0,1 \rightarrow 72,90$ & 7,29 \\
\hline & $\mathrm{R}=0,2 \rightarrow 276,60$ & 27,66 & $\mathrm{R}=0,2 \rightarrow 149,40$ & 14,94 & $\mathrm{R}=0,2 \rightarrow 64,80$ & 6,48 \\
\hline & $\mathrm{R}=0,3 \rightarrow 242,03$ & 24,20 & $\mathrm{R}=0,3 \rightarrow 130,73$ & 13,07 & $\mathrm{R}=0,3 \rightarrow 56,70$ & 5,67 \\
\hline & $\mathrm{R}=0,4 \rightarrow 207,45$ & 20,75 & $\mathrm{R}=0,4 \rightarrow 112,05$ & 11,21 & $\mathrm{R}=0,4 \rightarrow 48,60$ & 4,86 \\
\hline & $\mathrm{R}=0,5 \rightarrow 172,88$ & 17,29 & $\mathrm{R}=0,5 \rightarrow 93,38$ & 9,34 & $\mathrm{R}=0,5 \rightarrow 40,50$ & 4,05 \\
\hline \multirow{5}{*}{$\mathrm{F}_{\mathrm{q}}(\mathrm{kN})$} & $\mathrm{R}=0,1 \rightarrow 32,93$ & 8,23 & $\mathrm{R}=0,1 \rightarrow 17,79$ & 4,45 & $\mathrm{R}=0,1 \rightarrow 7,71$ & 1,93 \\
\hline & $\mathrm{R}=0,2 \rightarrow 65,86$ & 16,46 & $\mathrm{R}=0,2 \rightarrow 35,57$ & 8,89 & $\mathrm{R}=0,2 \rightarrow 15,43$ & 3,86 \\
\hline & $\mathrm{R}=0,3 \rightarrow 98,79$ & 24,70 & $\mathrm{R}=0,3 \rightarrow 53,36$ & 13,34 & $\mathrm{R}=0,3 \rightarrow 23,14$ & 5,79 \\
\hline & $\mathrm{R}=0,4 \rightarrow 131,71$ & 32,93 & $\mathrm{R}=0,4 \rightarrow 71,14$ & 17,79 & $\mathrm{R}=0,4 \rightarrow 30,86$ & 7,71 \\
\hline & $\mathrm{R}=0,5 \rightarrow 164,64$ & 41,16 & $\mathrm{R}=0,5 \rightarrow 88,93$ & 22,23 & $\mathrm{R}=0,5 \rightarrow 38,57$ & 9,64 \\
\hline
\end{tabular}

According to Lima [4], the bending reinforcement geometric ratio $\rho$ of the slab for central, border and edge columns are, respectively: $0,856 \% ; 0,663 \%$ and $0,482 \%$. These values were directly adopted from the cases analyzed by Lima [4] for all the reliability analysis of set 1 . For the set 2, as the slab thickness varied, new bending reinforcement geometric ratios were calculated, remaining the same concrete strength.

\section{RESULTS AND DISCUSSION}

\subsection{Central Column}

Figure 5 shows the evolution of the reliability index for each loading ratio considering the two critical contours $C$ and $C^{\prime}$. Two cases of solicitation were analyzed: only the axial force $F$ and axial force plus the two bending moments $M_{x}$ and $M_{y}$. The model error $E_{m}$ was considered only in the contour $C^{\prime}$ with all the solicitations simultaneously.

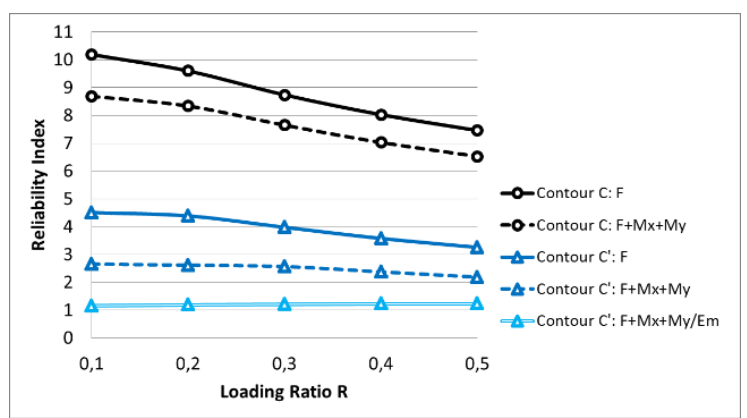

Figure 5. Reliability index $\times$ loading ratio: set 1 central column. 
The sensitivity factors of the random variables are depicted in Figure 6 . These sensitivity factors represent the relative importance of each R.V. in the reliability indices for the analyzed failure modes. The higher the sensitivity factor, the higher is the influence of that R.V. on the safety measure of the slab-column connection. As we can see, for the critical perimeter $C$, the reliability indices were very high (above 6,0), indicating high safety levels for this failure mode. The results represent the consulted experimental test and are in agreement with the evidences, in which, there was no observed punching shear failure at the interface slab-central column. For the critical perimeter $\mathrm{C}$, the sensitivity factors showed the most influential random variables on the probability of failure: concrete compressive strength $f_{c}$ and the live load $F_{q}$ for $\mathrm{R} \geq 0,2$ (Figure 6a). These results are coherent, since the concrete compressive strength is the only random variable in the $R(X)$ for the limit state function of the contour $C$. On the other hand, the live load has the higher coefficient of variation $(25 \%)$, which means the higher variability among the solicitation random variables.

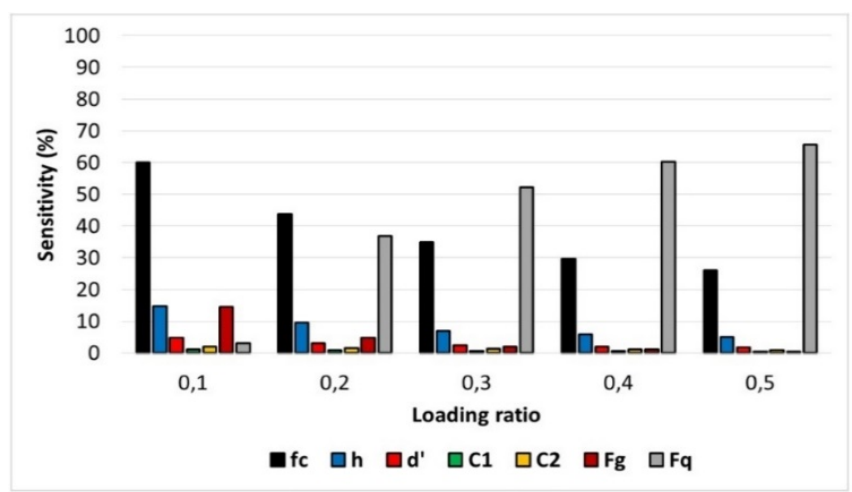

a) Contour $\mathrm{C}-\mathrm{Axial}$ force $\mathrm{F}$

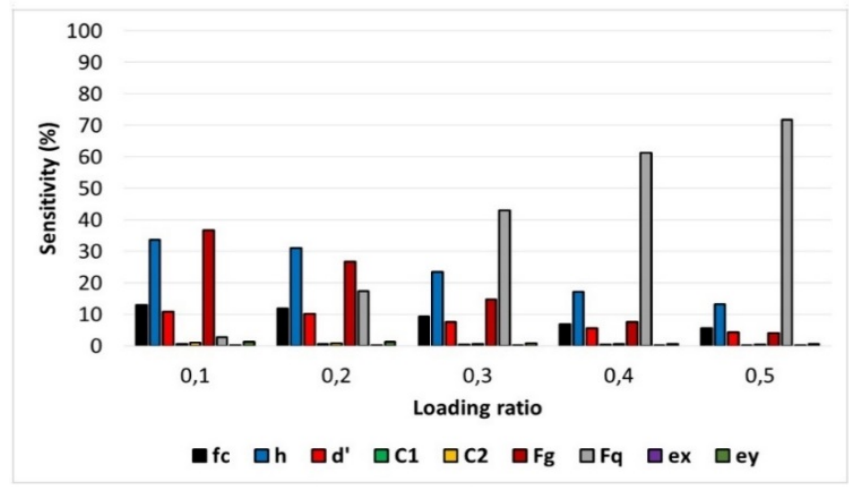

b) Contour C' $-\mathrm{F} ; \mathrm{M}_{\mathrm{x}} ; \mathrm{M}_{\mathrm{y}}$ without model error

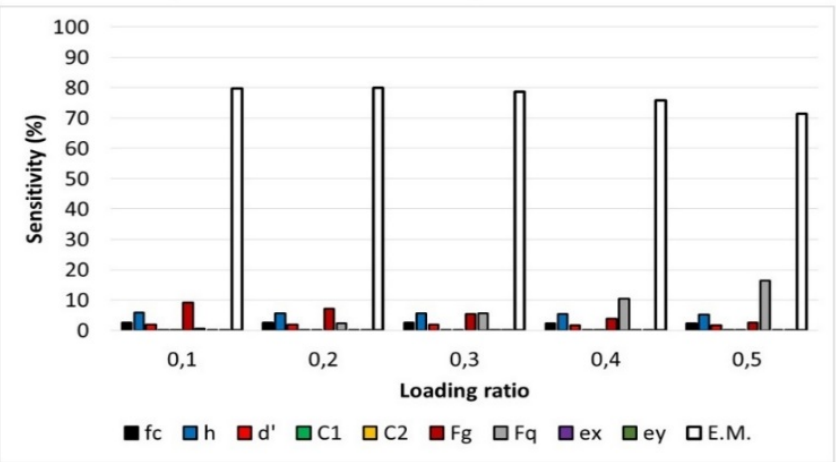

c) Contorno C' $-\mathrm{F} ; \mathrm{M}_{\mathrm{x}} ; \mathrm{M}_{\mathrm{y}}$ with model error

Figure 6. Sensitivity factors $\times$ loading ratio: set 1 central column.

In general, for cases without model error, the reliability index decreased as the loading ratio increased because the influence of the live load portion at the total solicitation increased too. However, as shown in Figure 6b, the most 
significant random variables for the contour $C^{\prime}$ was the slab thickness and the live load. The slab thickness plays a doubly important role on the slab-column connections punching shear resistance, since they increase the resistant portion $R(X)$ and decrease the solicitation portion $S(X)$. In comparison to the target (minimum) reliability index of 3,8, the observed safety levels were below the referenced target value. Thus, depending on the sensitivity of the random variables, for the analyzed case, it is possible to recommend increasing the slab thickness to improve the safety of the connection against punching shear.

When the model error $E_{m}$ was considered, the reliability index remained practically constant regardless of the increase in $R$. The sensitivity factors (Figure $6 \mathrm{c}$ ) showed that the influence of the model error was always preponderant, even with the increase of the live load. For central columns, the model error has mean value less than 1,0 and almost $20 \%$ coefficient of variation, which means a reduction on the $R(X)$ with high variability. Therefore, a large decrease in $\beta$ was observed when compared to the same case of failure in the contour $C^{\prime}$ without model error. This evidence is coherent and may be an indication of the need to improve the quality of the punching shear theoretical prediction model and/or the partial design factor for punching failure should be revised. For all the analyzed cases, the random variables of geometry, which are, cross section column dimensions and eccentricities did not show significant influence on $P_{f}$.

Figure 7 shows the set 2 of analyzes. The results shown refer only to the $\beta$ for the contour $C^{\prime}$ with axial force and both bending moments, without and with model error. The analytical analysis based on the punching shear prediction model presented in the Brazilian code indicated that the acting shear stress is less than the contour $C$ ' resistance only when the slab thickness reaches $23 \mathrm{~cm}$. Regardless of the loading ratio, for $h=23 \mathrm{~cm}$, the reliability indices were greater than 4,0, indicating a sufficient safety level for the slab-column connection. However, for $h=22 \mathrm{~cm}$, considering the probabilistic analysis via structural reliability theory, the target condition of $\beta \geq 3,8$ is satisfied. When the model error (Figure $7 \mathrm{~b}$ ) is considered, it was observed that the lack of uniformity of $\beta$ for different values of $R$ (Figure 7a) was eliminated. On the other hand, a great reduction in $\beta$ values was observed, even for high slab thickness. Again, this occurred due to a mean value of the model error less than 1 and high uncertainty associated with the prediction model of the Brazilian code.

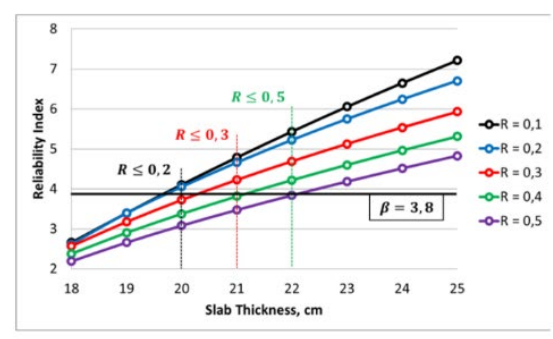

a) Contour C' - Without model error

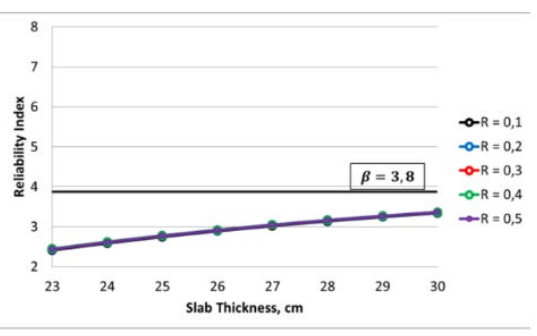

b) Contour C' - With model error

Figure 7. Reliability index $\times$ slab thickness: set 2 central columns.

\subsection{Border Column}

Figure 8 shows the results in terms of $\beta$ for the critical contours $C, C^{\prime}$ with and without $E_{m}$ for all the loading ratios in two situations: the axial force $F$ plus the bending moment $M_{x}$ and axial force $F$ plus the two bending moments $M_{x}$ and $M_{y}$. The model



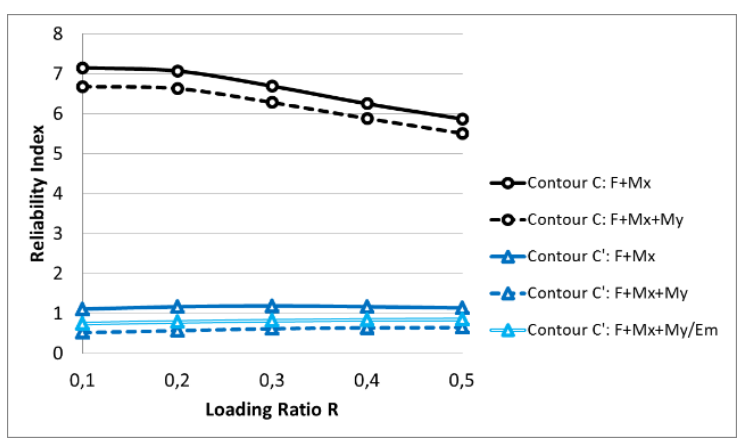

Figure 8. Reliability index $\times$ loading ratio: set 1 border column. 
As observed for the central pillar, the reliability indices obtained for the contour $C$ were very high (above 5,0), indicating high safety levels.

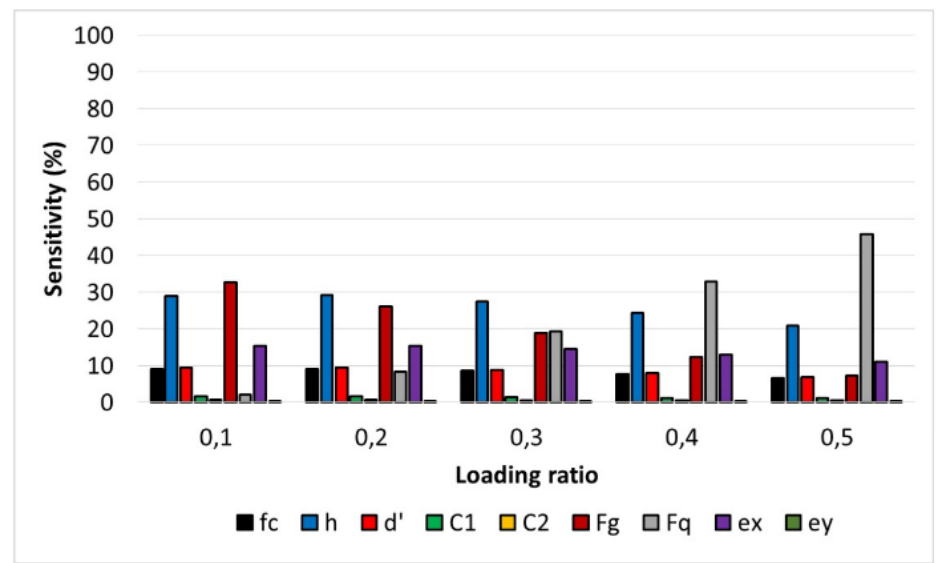

a) Contour $\mathrm{C}^{\prime}-\mathrm{F} ; \mathrm{M}_{\mathrm{x}} ; \mathrm{M}_{\mathrm{y}}$ without model error



b) Contorno C' $-\mathrm{F} ; \mathrm{M}_{\mathrm{x}} ; \mathrm{M}_{\mathrm{y}}$ with model error

Figure 9. Sensitivity factors $\times$ loading ratio: set 1 border column.

Figure 9 presents the sensitivity factors for some of the contour $C^{\prime}$ analyzes. Regarding the contour $C$, the same observed behavior in the central column was maintained. For the contour $C$ ', the reliability indices showed little variation for all the loading ratios, differently from the central column. The most important random variables were the eccentricity $e_{x}=48 \mathrm{~cm}$, in addition with slab thickness and the live load. The inclusion of the model error, in this case, increased the reliability indices regarding the same condition in contour $C^{\prime}$ without model error. The model error was also the most influent variable, with sensitivity factor varying between $55 \%$ and $65 \%$.

When the model error was considered, the reliability indices have increased because of the elevated mean value, even with coefficient of variation equal to $21,4 \%$ (Table 1). As we can see, slab thickness of $18 \mathrm{~cm}$ is insufficient $(\beta<1.0)$ for the contour $C^{\prime}$, when the probabilistic approach is adopted.

The results shown in Figure 10 refer to the analyzes of set 2 only to the $\beta$ for the contour $C^{\prime}$, with axial force and both bending moments, without and with model error, for different loading ratios. The theoretical analysis based on the prediction model of the Brazilian code indicated that the minimum slab thickness for the contour $C^{\prime}$ is $25 \mathrm{~cm}$ (Figure 10a). Regardless of the loading ratio, for $\mathrm{h}=25 \mathrm{~cm}$ without model error, $\beta$ is greater than or equal to 4,0 , indicating a sufficient safety level when compared to the $\beta_{\text {target }}=3,8$. Therefore, both analyzes (normative and probabilistic) resulted in the same slab thickness, regardless of the adopted loading ratio. When the model error was considered, the reliability indices resulted lower than those without $E_{m}$ (Figure 10b). This result is coherent, since the coefficient of variation of the model error is high, which introduces more uncertainty in the predicted mechanical response by the normative theoretical model. 


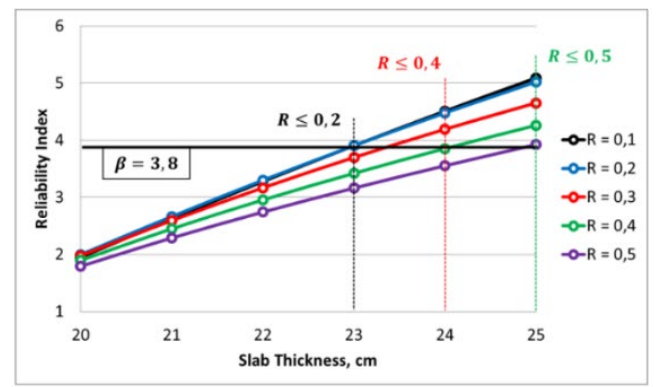

a) Contour C' - Without model error

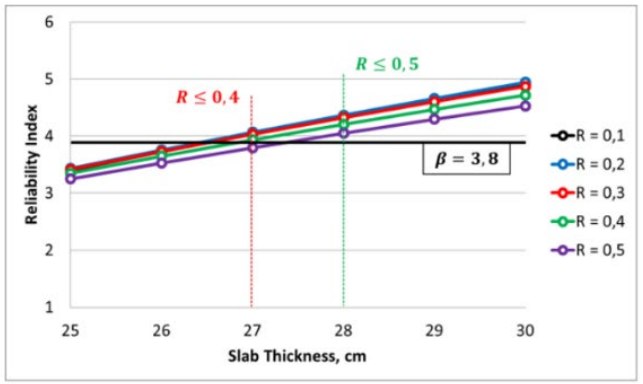

b) Contour C' - With model error

Figure 10. Reliability index $\times$ slab thickness: set 2 border column.

\subsection{Edge Column}

Figure 11 shows the results in terms of $\beta$ for the critical contours $C, C^{\prime}$ with and without $E_{m}$ for all the loading ratios in just one situation: the axial force $F$ plus the most important bending moment, $M_{x}$. Regarding the contour $C$, the same observed behavior for the central and border columns has occurred with very high reliability index values (above 6,0 ). The reliability indices remained almost constant for all the loading ratio values. When the model error was considered,


even with a high coefficient of variation $(29,7 \%$ ), the mean value of 1,363 (Table 1 ) increased significantly the contour $C$ ' reliability indices. However, the statistical characterization of the edge column model error was not really adequate as done for the central and border column, since the experimental sample size was reduced. The obtained results for the contour $C^{\prime}$ clearly showed that the adopted slab thickness of $18 \mathrm{~cm}$ is insufficient to resist punching shear without transversal reinforcement.



Figure 11. Reliability index $\times$ loading ratio: set 1 edge column.

Figure 12 presents the sensitivity factors of the random variables for some analyzed cases. Regarding the contour $C^{\prime}$ without model error, the most important random variables were the slab thickness, live load and the eccentricity $e_{x}$. The model error remained dominant when compared to the other random variables, achieving almost $80 \%$ of sensitivity for all loading ratios.

Figure 13 presents the reliability indices evolution for the set 2 . As observed for the border column, the minimum slab thickness to achieve the normative requirements was $25 \mathrm{~cm}$. In the reliability analysis, for $\mathrm{h}=25 \mathrm{~cm}$, the $\beta_{\text {target }}=3,8$ was also achieved for all the loading ratios, in the case without model error. When the model error was considered, the minimum value for the slab thickness to achieve the $\beta_{\text {target }}$ increased to $29 \mathrm{~cm}$, due to the high value of the coefficient of variation of the $E_{m}$. 


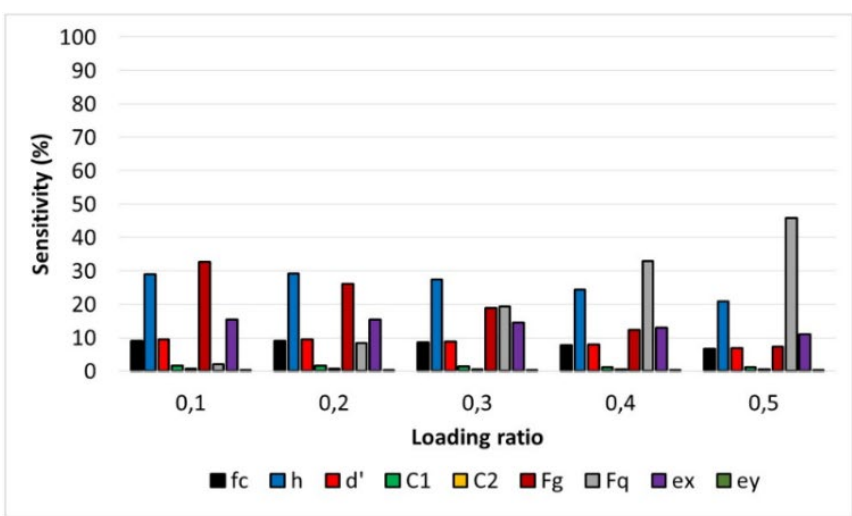

a) Contour C' $-\mathrm{F} ; \mathrm{M}_{\mathrm{x}}$ without model error

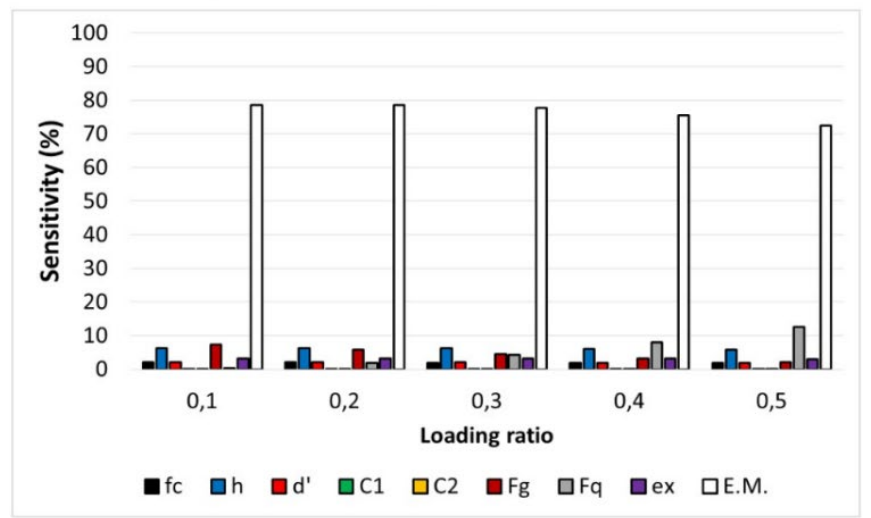

b) Contorno C' $-\mathrm{F} ; \mathrm{M}_{\mathrm{x}}$ with model error

Figure 12. Sensitivity factors $\times$ loading ratio: set 1 edge column.

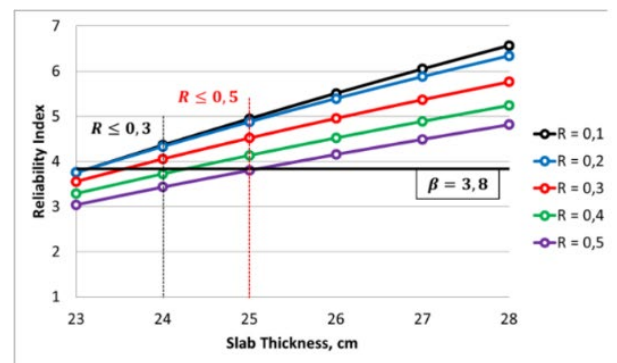

a) Contour C' - Without model error

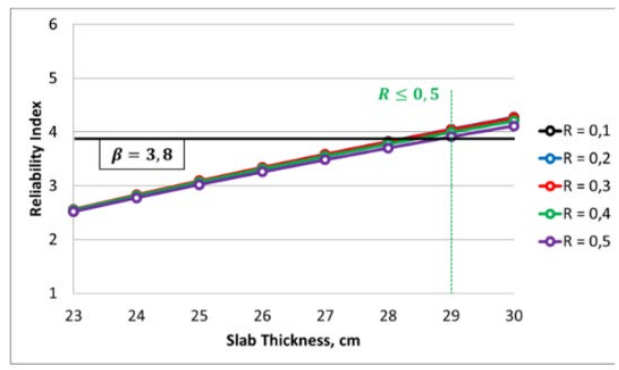

b) Contour C' - With model error

Figure 13. Reliability index $\times$ slab thickness: set 2 edge columns.

\section{CONCLUSIONS}

This paper presented a study about the safety of the slab-column connections subjecting to punching shear for central, border and edge columns in a flat slab reinforced concrete building proposed by Lima [4]. From a probabilistic approach via Structural Reliability Theory, combined with the ABNT NBR 6118 [35] analytical punching shear prediction model and the model error random variable, the performance of these connections in terms of the reliability index was evaluated. The model error was characterized from several experimental results consulted in the literature for the three analyzed columns.

The conclusions of this study are summarized below:

- The high $\beta$ values associated with the contour $C$ proved to be consistent with the type of failure observed in the experimental tests, in which these always occurred in the vicinity of the contour $C^{\prime}$. Therefore, it can be concluded that the punching shear rupture will hardly occur at the slab-column interface, since the normative recommendations in the project be respected; 
- When the model error was considered as a random variable in the performed analyzes, especially for the central and border column, it was observed a strong uniformity of the results in terms of $\beta$, in comparison to the results without the model error. The constructed statistics of the model error showed, in general, that the Brazilian code punching shear prediction model presented good quality in average terms, but with loss of precision because of its high values of coefficient variation. This is due to the complexity of the punching shear phenomenon and the difficulty of translating it into a simple and direct analytical model, as well as the lack of standardization of the experimental tests until mechanical failure. The improvement of the theoretical prediction models is a complex task and should not be seen, in the light of what has been presented here, simply by multiplying the resistant portion $R(X)$ by the obtained model error calibrated value;

- In terms of the slab-column connection failure to punching shear, the most important parameters, without model error, were the total slab thickness and the concrete compressive strength. There was no significant influence of the column cross section dimensions on the probability of failure of the analyzed cases. However, the axial force eccentricities that generate the bending moments have shown some importance when their values were higher. This further emphasizes the stage of structural analysis of the flat slab systems, in order to accurately obtain the bending moments acting on the slab-column connections; Thus, in the flat slab design subjected to punching shear, the most important parameters of the slab-column connections can be controlled by the engineer, which can be an important measure to structural safety guarantee. On the other hand, when the model error was considered, it was the most important variable with more than $60 \%$ of influence on the probability of failure, followed by the slab thickness and concrete compressive strength, regardless the variations on the loading ratio;

- As observed in this study, the appropriate slab thickness, for all the considered loading ratio, was achieved based on a target reliability-based criterion. The obtained values for $h$ without $E_{m}$ were very close to those obtained according to the semi-probabilistic procedure adopted by the Brazilian normative, when considering the partial safety factors and all the code recommendations. However, when the model error was considered, the safety levels significantly decreased, suggesting the importance of improving the quality of the Brazilian normative prediction model for punching shear.

\section{ACKNOWLEDGMENTS}

The authors would like to thank FAPESP (process n 2018/06562-4) for the scholarship granted to the student and the UNESP - Bauru Campus for all the support.

\section{REFERENCES}

[1] M. L. Carvalho, C. R. Silva, and F. R. Stucchi, "Estudo da confiabilidade da punção em lajes lisas sem armadura de cisalhamento de acordo com a NBR 6118," Rev. IBRACON Estrut. Mater., vol. 10, no. 2, pp. 276-297, Apr 2017.

[2] J. Einpaul, C. E. Ospina, M. F. Ruiz, and A. Muttoni, "Punching shear capacity of continuous slabs," ACI Struct. J., vol. 113, pp. 861-872, 2016.

[3] E. A. P. Liberati, M. G. Marques, E. D. Leonel, L. C. Almeida, and L. C. Trautwein, "Failure analysis of punching in reinforced concrete flat slabs with openings adjacent to the column," Eng. Struct., no. 182, pp. 331-343, 2019.

[4] J. S. Lima, "Verificações da punção e da estabilidade global em edifícios de concreto: desenvolvimento e aplicações normativas," M.S. thesis, Esc. Eng. São Carlos, Univ. São Paulo, São Carlos, 2001.

[5] N. G. B. Albuquerque, "Comportamento das ligações de lajes lisas de concreto armado com pilares de borda sujeitas a excentricidades interna e externas," Ph.D. dissertation, Fac. Tecnol., Univ. Brasília, Brasília, 2014.

[6] J. L. P. Melges, "Punção em lajes: exemplos de cálculo e análise teórico-experimental,” M.S. thesis, Esc. Eng. São Carlos, Univ. São Paulo, São Carlos, 1995.

[7] J. L. P. Melges, “Análise experimental da punção em lajes de concreto armado e protendido,” Ph.D. dissertation, Esc. Eng. São Carlos, Univ. São Paulo. São Carlos, 2001.

[8] D. R. C. Oliveira, “Análise experimental de lajes cogumelo de concreto de alta resistência com armadura inclinada de punção,” M.S. thesis, Univ. Brasília, Brasília, 1998.

[9] W. L. A. Oliveira, “Análise teórico-experimental de pilares mistos preenchidos de seção circular,” Ph.D. dissertation, Univ. São Paulo, São Carlos, 2008.

[10] O. S. Paiva, "Análise do efeito da retangularidade dos pilares nos critérios normativos de dimensionamento à punção em lajes lisas de concreto armado,” M.S. thesis, Univ. Fed. Pará, Belém, 2013. 
[11] J. B. L. Libório, "Estudo experimental da ruína de ligações laje-pilar em bordas com pilares de seção retangular,” M.S. thesis, Esc. Eng. São Carlos, Univ. São Paulo, São Carlos, 1985.

[12] L. S. R. Damasceno, “Análise experimental de lajes lisas unidirecionais de concreto armado com pilares retangulares ao puncionamento,” M.S. thesis, Univ. Fed. Pará, Inst. Tecnol., Dep. Eng. Civ., Belém, 2007.

[13] M. P. Ferreira, "Análise experimental de lajes lisas unidirecionais de concreto armado ao puncionamento simétrico ou assimétrico," M.S. thesis, Univ. Fed. Pará, Cent. Tecnol., Belém, 2006.

[14] D. A. O. Martinelli, “A ruína das ligações laje-pilar nos cantos de lajes-cogumelo,” Ph.D. dissertation, Esc. Eng. São Carlos, Univ. São Paulo, São Carlos, 1974.

[15] F. M. H. Feliciano, "Punção em lajes lisas de concreto armado com pilares de borda e excentricidade externa," M.S. thesis, Fac. Tecnol., Univ. Brasília, Brasília, 2011.

[16] R. M. Gonçalves, "Estudo experimental da ruína de ligações laje-pilar em bordas de lajes cogumelo com reforço transversal constituído de perfis metálicos,” M.S. thesis, Univ. São Paulo, São Carlos, 1986.

[17] V. C. Mouro, "Punção em lajes cogumelo: estudo da retangularidade dos pilares,” M.S. thesis, Univ. Fed. Goiás, Goiânia, 2006.

[18] T. Takeya, "Estudo experimental da ruína de ligações laje-pilar em bordas de lajes-cogumelo,” M.S. thesis, Esc. Eng. São Carlos, Univ. São Paulo, São Carlos, 1981.

[19] N. J. Gardner, "Relationship of the punching shear capacity of reinforced concrete slabs with concrete strength," ACI Struct. J., vol. 87, no. 1, pp. 66-71, 1990.

[20] R. B. Gomes and P. E. Regan, "Punching resistance of RC flat slabs with shear reinforcement," J. Struct. Eng., vol. 125, no. 6, pp. 684-692, Jun 1999.

[21] N. M. Hawkins, H. B. Falssen, and R. C. Hinojosa, Influence of Column Rectangularity on the Behaviour of Flat Plate Structures (Publication SP-30). Detroit: Am. Concr. Inst., 1971, pp. 127-146.

[22] H. Marzouk and A. Hussen, "Experimental investigation on the behavior of high-strength concrete slabs," ACI Struct. J., vol. 88, no. 6, pp. 701-713, 1992.

[23] J. D. Mortin and A. Ghali, "Connection of flat plates to edge columns," ACI Struct. J., vol. 88, no. 2, pp. 191-198, 1991.

[24] P. E. Regan and H. Rezai-Jorabi, "Shear resistance of one-way slabs under concentrated loads," ACI Struct. J., vol. 85, no. 2, pp. 150-158, Mar-Apr 1988.

[25] P. E. Regan, Tests of Connections between Flat Slabs and Edge Columns. London: Sch. Archit. Eng., Univ. Westminter, 1993

[26] A. Sherif, M. B. Emara, A. Hassanein, and S. A. Magd, "Effect of the column dimensions on the punching shear strength of edge column-slab connections," in Punching Shear in Reinforced Concrete Slabs (ACI Special Publication 232), 2005, pp. 175-192.

[27] A. G. Sherif and W. H. Dilger, "Punching failure of full-scale high strength concrete flat slabs," in Int. Workshop on Punching Shear Capacity of RC Slabs (TRITA-BKN Bulletin 57), Stockholm, Sweden, 2000, pp. 235-243.

[28] E. R. F. Zaghlool, "Strength and behavior of corner and edge column-slab connections in reinforced concrete flat plates," Ph.D. dissertation, Dept. Civ. Eng., Univ. Calgary, 1971.

[29] M. J. M. Pereira Fo., M. V. P. Freitas, D. F. A. Santos, A. J. C. Nascimento, and M. P. Ferreira, "Slabs strengthened for punching shear with post-installed steel and CFRP connectors," Ibracon Struct. Mater. J., vol. 12, no. 3, pp. 445-478, 2019.

[30] A. M. D. Souza and M. K. El Debs, "Shear strength analysis of slabs without transverse reinforcement under concentrated loads according to ABNT NBR 6118:2014," Ibracon Struct. Mater. J., vol. 12, no. 3, pp. 658-693, Jun 2019.

[31] C. B. Carvalho, “Análise crítica dos critérios normativos de dimensionamento à punção em lajes lisas,” M.S. thesis, Esc. Eng., Univ. Fed. Minas Gerais, Belo Horizonte, 2008.

[32] V. P. Barros, A. T. Beck, and T. N. Bittencourt, "Shear failure in reinforced concrete members without transverse reinforcement: analysis of model error of NBR 6118:2014," Ibracon Struct. Mater. J., vol. 14, no. 1, 2020.

[33] G. R. Silva, A. Campos Fo., and M. V. Real, "Reliability of internal column-slab connection under punching according to NBR 6118:2014," Ibracon Struct. Mater. J., vol. 11, no. 5, pp. 931-948, Oct 2018.

[34] E. A. P. Liberati, “Análise de confiabilidade de lajes lisas de concreto armado submetidas à punção,” Ph.D. dissertation, Fac. Eng. Civil, Arquit. Urban., Univ. Est. Campinas, Campinas, 2019.

[35] Associação Brasileira de Normas Técnicas, Projeto de Estruturas de Concreto - Procedimento, NBR 6118, 2014.

[36] L. L. J. Borges, G. S. Melo, R. B. Gomes, and R. M. Bittencourt, "Influência da geometria do pilar na resistência ao puncionamento de lajes cogumelo de concreto armado," in An. V Simp. EPUSP Estrut. Concr., São Paulo, 2003.

[37] J. A. Silva and R. B. Gomes, "Resistência à punção de lajes cogumelo de concreto armado com armadura de cisalhamento, furos e colunas retangulares," in An. V Simpósio EPUSP sobre Estrut. Concr., São Paulo, 2003.

[38] B. N. Moraes No., “Análise experimental de lajes lisas bidirecionais de concreto armado com estribos inclinados e pilares retangulares sujeitas a puncionamento simétrico,” M.S. thesis, Univ. Fed. Pará, Belém, 2007. 
[39] N. Narasimhan, "Shear reinforcement in reinforced concrete column heads,” Ph.D. dissertation, Fac. Eng. Univ. London, London, 1971.

[40] E. F. El-Salakawy, M. A. Polak, and M. H. Soliman, "Slab-column edge connections subjected to hight moments," Can. J. Civ. Eng., vol. 25 , no. 3, pp. 526-538, 1998.

[41] K. Sudarsana, "Punching shear in edge and corner column slab connections of flat plate structures," Ph.D. dissertation, Univ. Ottawa. Ottawa, 2001.

[42] D. A. O. Martinelli, “A ruína das ligações laje-pilar nos cantos de lajes-cogumelo,” Ph.D. dissertation, Esc. Eng. São Carlos, Univ. São Paulo. São Carlos, 1974.

[43] Comitê Europeu de Normalização, Design of Concrete Structures - Part 1-1: General Rules and Rules for Buildings, Eurocode 2, 2010.

[44] A. H.-S. Ang and W. H. Tang, Probability Concepts in Engineering Planning and Design - vol. II: Decision, Risk and Reliability. New York: John Wiley \& Sons, 1984.

[45] A. T. Beck, Confiabilidade e Segurança das Estruturas, 1ª ed. Rio de Janeiro: Elsevier, 2019.

[46] A. M. Hasofer and N. C. Lind, "Exact and invariant second moment code format," J. Eng. Mech. Div., vol. 100, no. EM1, pp. 111121, Feb 1974.

[47] Joint Committee on Structural Safety, Probabilistic Model Code: Part 1 - Basis of Design. Denmark: JCSS, 2000,64 p.

[48] Comitê Europeu de Normalização, Eurocode - Basis of Structural Design, EN 1990, 2002.

[49] G. P. Pellizzer, "Sobre a modelagem numérica da difusão de cloretos no concreto: uma abordagem pelo método dos elementos de contorno com aplicação de modelos de confiabilidade e otimização,” Ph.D. dissertation, Univ. São Paulo, 2019.

[50] C. G. Nogueira, W. S. Venturini, and A. T. Beck, "Avaliação da confiabilidade de ligações laje-pilar à punção a partir do Modelo da NBR 6118:2003," in An. XXVIII Cong. Ibero Latino-Am. Métodos Comput. Eng., Congresso de Mét. Num. Eng. CMNE 2007, Portugal, 2007.

[51] G. R. Silva, “Análise da confiabilidade da ligação laje-pilar interno sob punção de acordo com a NBR-6118:2014,” M.S. thesis, Univ. Fed. Rio Grande do Sul, Porto Alegre, 2017.

[52] M. L. Carvalho, C. R. Silva, and F. R. Stucchi, "Study on reliability of punching shear of flat slabs without shear reinforcement according to NBR6118," Rev. IBRACON Estrut. Mater., vol. 10, no. 2, pp. 276-297, Apr 2017.

[53] B. Ellingwood and T. V. Galambos, "Probability-based criteria for structural design," Struct. Saf., vol. 1, pp. 15-26, 1982.

[54] R. Rachwitz and B. Fiessler, "Structural reliability under combined random load sequences," Comput. Struc., vol. 9, pp. 489-494, 1978.

[55] A. S. Nowak and K. R. Collins, Reliability of Structures. Michigan: McGraw Hill, 2000.

[56] C. G. Nogueira, "Desenvolvimento de modelos mecânicos, de confiabilidade e de otimização para aplicação em estruturas de concreto armado,” Ph.D. dissertation, Esc. Eng. São Carlos, Univ. São Paulo, 2010.

[57] E. S. Santos, "Avaliação estatística do erro de modelos de resistência para elementos lineares de concreto armado da ABNT NBR6118:2007,” M.S. thesis, Univ. São Paulo, São Carlos, 2012.

[58] E. A. Bolandim, “Análise de confiabilidade em ligações parafusadas em chapas finas e perfis de aço formados a frio,” M.S. thesis, Univ. São Paulo. São Carlos, 2011.

[59] W. L. A. Oliveira, “Análise teórico-experimental de pilares mistos preenchidos de seção circular,” Ph.D. dissertation, Univ. São Paulo. São Carlos, 2008.

[60] E. A. P. Liberati, L. M. Trautwein, E. D. Leonel, R. K. T. Marques, and L. C. Almeida "Avaliação estatística de erro de modelos de resistência à punção de lajes lisas de concreto armado" in An. 59 Cong. Bras. Concr. IBRACON2017, Bento Gonçalves, 2017.

Author contributions: NLAM: Data curation, formal analysis, investigation, methodology, validation, writing-original draft; CGN:

Conceptualization, funding acquisition, supervision, formal analysis, investigation, methodology, project administration, software, writing-review \& edition.

Editors: Antonio Carlos dos Santos, Guilherme Aris Parsekian. 


\section{APPENDIX}

Tables A1, A2 and A3 show the data set of each literature reference used in this study for central, border and edge slab-column connection, respectively. It is also presented the punching shear ultimate loads observed in the experiments and the predicted loads by the ABNT NBR 6118 [35].

Table A1. Data for central column.

\begin{tabular}{ccccccc}
\hline Reference & Slabs & $\mathbf{f}_{\mathbf{c}}(\mathbf{M P a})$ & $\mathbf{d} \mathbf{( \mathbf { c m } )}$ & $\boldsymbol{\rho}(\mathbf{\%})$ & $\mathbf{F}_{\mathbf{e x p}} \mathbf{( k N )}$ & $\mathbf{F}_{\text {teo }}(\mathbf{k N})$ \\
\hline $\begin{array}{c}\text { Carvalho apud } \\
\text { Gardner [19] }\end{array}$ & 21 & $12.8-37.4$ & $11.4-11.8$ & $1.2-7.0$ & $280.2-533.8$ & $307.6-696.2$ \\
\hline $\begin{array}{c}\text { Moe apud Gardner } \\
\text { [19] }\end{array}$ & 13 & $20.5-35.2$ & 11.4 & $1.0-1.5$ & $311.4-432.8$ & $324.7-426.9$ \\
\hline $\begin{array}{c}\text { Marzouk and Hussein } \\
\text { [22] }\end{array}$ & 14 & $30.0-80.0$ & $9.0-12.0$ & $0.5-2.4$ & $178.0-645.0$ & $240.9-596.1$ \\
\hline $\begin{array}{c}\text { Melges [7] } \\
\text { Oliveira [9] }\end{array}$ & 1 & 26.6 & 12.7 & 1.7 & 441.6 & 416.7 \\
\hline Gomes and Regan [20] & 3 & $36.5-41.1$ & $15.9-16.3$ & 1.26 & $560.0-650.0$ & $628.8-633.4$ \\
\hline $\begin{array}{c}\text { Teng et al. apud Paiva } \\
\text { [10] }\end{array}$ & 5 & $36.0-43.0$ & $10.3-11.1$ & $1.65-1.81$ & $423.0-649.0$ & $383.7-576.4$ \\
\hline Borges et al. [36] & 9 & $36.2-44.7$ & $13.9-16.4$ & $1.28-1.58$ & $550.0-897.0$ & $571.9-931.2$ \\
\hline Silva and Gomes [37] & 3 & $39.6-40.8$ & 9 & 1.45 & $273.0-469.0$ & $269.5-366.5$ \\
\hline $\begin{array}{c}\text { Oliveira and Melo apud } \\
\text { Carvalho et al. [1] }\end{array}$ & 15 & $54.0-67.0$ & $10.6-11.0$ & 1.1 & $240.0-446.0$ & $320.2-351.4$ \\
\hline $\begin{array}{c}\text { Mouro apud Regan } \\
\text { and Rezai-Jarobi [24] }\end{array}$ & 6 & $29.0-38.2$ & 7.9 & $1.5-1.6$ & $77.0-132.0$ & $179.5-237.6$ \\
\hline Ferreira [13] & 11 & $36.1-58.0$ & $8.7-8.9$ & $0.9-1.5$ & $159.5-228.0$ & $192.9-238.8$ \\
\hline Mouro [17] & 8 & $22.0-29.0$ & $9.0-9.4$ & $1.4-1.5$ & $275.0-395.0$ & $275.2-311.1$ \\
\hline $\begin{array}{c}\text { Vilhena et al. apud } \\
\text { Paiva [10] }\end{array}$ & 4 & $51.2-55.2$ & 6.5 & $1.2-1.4$ & $122.0-124.5$ & $147.1-252.1$ \\
\hline Damasceno [12] & 3 & $41.3-42.0$ & $8.9-9.8$ & $0.6-1.2$ & $172.0-194.5$ & $192.0-217.3$ \\
\hline Moraes [38] & 2 & $39.4-39.8$ & 8.7 & $1.2-1.4$ & $224.0-241.0$ & $215.0-255.4$ \\
\hline Hawkins et al. [21] & 6 & $27.0-32.0$ & $11.7-12.1$ & $0.8-1.1$ & $321.0-358.0$ & $345.2-430.7$ \\
\hline
\end{tabular}

Table A2. Data for border column.

\begin{tabular}{ccccccc}
\hline Reference & Slabs & $\mathbf{f}_{\mathbf{c}} \mathbf{( M P a )}$ & $\mathbf{d} \mathbf{( c m})$ & $\boldsymbol{\rho} \mathbf{( \% )}$ & $\mathbf{F}_{\mathbf{e x p}} \mathbf{( k N )}$ & $\mathbf{F}_{\text {teo }}(\mathbf{k N})$ \\
\hline Narasimhan [39] & 3 & $27.0-32.1$ & 12.7 & 1.0 & $264.0-342.0$ & $217.0-229.9$ \\
\hline Kinnunen apud Albuquerque [5] & 3 & $23.4-26.6$ & 10.2 & $1.0-1.5$ & $128.0-169.0$ & $96.5-125.6$ \\
\hline Zaghlool [28] & 2 & $38.7-40.5$ & $11.7-12.1$ & $1.4-2.0$ & $247.0-268.0$ & $196.3-204.0$ \\
\hline Regan et al. apud Albuquerque [5] & 7 & $27.4-50.0$ & $9.8-10.1$ & $0.5-1.0$ & $114.0-192.0$ & $117.1-159.6$ \\
\hline Takeya [18] & 3 & $34.5-45.8$ & 8.5 & 1.8 & $122.7-125.8$ & $111.1-118.6$ \\
\hline Brandli et al. apud Albuquerque [5] & 2 & 34.6 & $16.3-16.7$ & $1.1-1.2$ & $345.0-360.0$ & $314.1-387.3$ \\
\hline Libório [11] & 9 & $22.0-43.9$ & 6.0 & 1.9 & $54.1-98.4$ & $40.4-72.3$ \\
\hline Gonçalves [16] & 3 & $42.8-46.5$ & 8.5 & 1.8 & $110.0-117.8$ & $119.3-122.7$ \\
\hline Mortin and Ghali [23] & 2 & $32.2-43.2$ & 12.2 & $0.7-1.0$ & $105.0-141.0$ & $118.2-146.9$ \\
\hline El-Salakawy et al. [40] & 2 & $33.0-36.5$ & 10.0 & 0.6 & $69.4-125.0$ & $63.6-111.7$ \\
\hline Regan [25] & 10 & $35.4-42.7$ & 16.8 & $0.5-0.8$ & $233.0-416.0$ & $200.2-293.6$ \\
\hline Lim and Rangan apud Albuquerque [5] & 1 & 25.0 & 9.8 & 0.3 & 106.0 & 94.5 \\
\hline Sherif and Dilger [27] & 2 & $28.0-84.1$ & 11.4 & $1.3-1.4$ & $185.0-245.0$ & $195.5-195.8$ \\
\hline Afhami et al. apud Albuquerque [5] & 2 & 34.8 & 11.6 & $0.5-1.0$ & $181.0-220.0$ & $158.9-162.3$ \\
\hline Sudarsana [41] & 11 & $33.9-44.0$ & 10.5 & $0.9-1.2$ & $79.8-220.0$ & $83.2-163.4$ \\
\hline Sherif et al. [26] & 5 & $31.0-35.6$ & 10.0 & $1.0-1.2$ & $95.0-172.0$ & $99.8-153.0$ \\
\hline Feliciano [15] & 4 & 45.1 & 15.2 & 0.75 & $197.5-300.0$ & $254.9-295.4$ \\
\hline Albuquerque [5] & 3 & $44.8-50.1$ & $14.6-14.7$ & $1.0-1.3$ & $308.0-374.0$ & $312.7-348.2$ \\
\hline
\end{tabular}


Tabela A3. Data for edge column.

\begin{tabular}{|c|c|c|c|c|c|c|}
\hline Reference & Slabs & $\mathbf{f}_{\mathrm{c}}(\mathrm{MPa})$ & d (cm) & $\rho(\%)$ & $F_{\exp }(\mathbf{k N})$ & $F_{\text {teo }}(\mathbf{k N})$ \\
\hline Narasimhan [39] & 1 & 34.1 & 15.1 & 1.0 & 385.0 & 147.8 \\
\hline Martinelli [42] & 8 & $41.1-47.3$ & 8.5 & 1.8 & $60.3-66.3$ & $47.0-49.3$ \\
\hline Sudarsana [41] & 4 & 44.4 & 10.5 & 1.1 & $62.1-108.6$ & $74.5-84.6$ \\
\hline
\end{tabular}

For each slab-column connection, Figures A1, A3 and A5 illustrate the trend of the model error regarding some design parameters, such as: reinforcement geometric ratio $(\rho)$, concrete compressive strength $\left(f_{c}\right)$, slab serviceable thickness $(d)$ and eccentricity $(e)$. In addition, Figures A2, A4 and A6 show the accuracy of the ABNT NBR 6118 [35] prediction model for punching shear failure.


Figure A1. Influence of $\rho, f_{c}$ and $d$ on the model error for central columns.

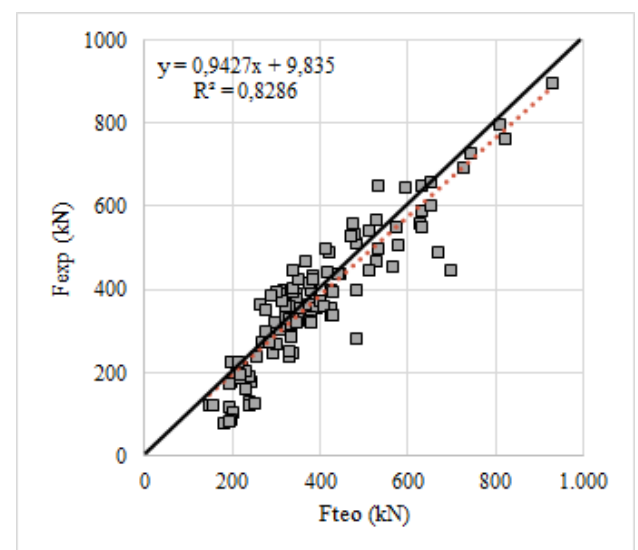

Figure A2. Accuracy of the Brazilian standard punching shear prediction model for central columns. 

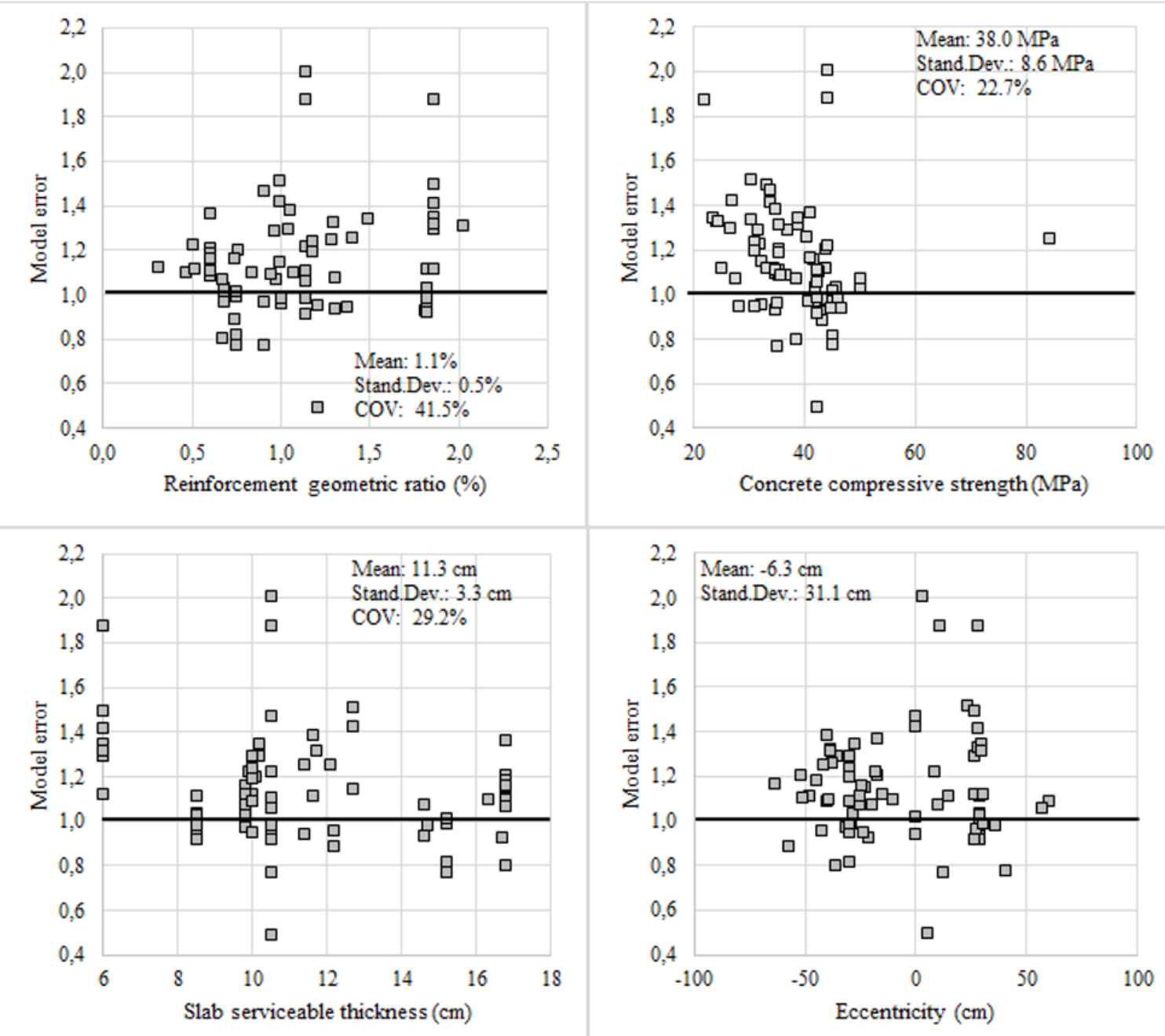

Figure A3. Influence of $\rho, f_{c}, d$ and $e$ on the model error for border columns.

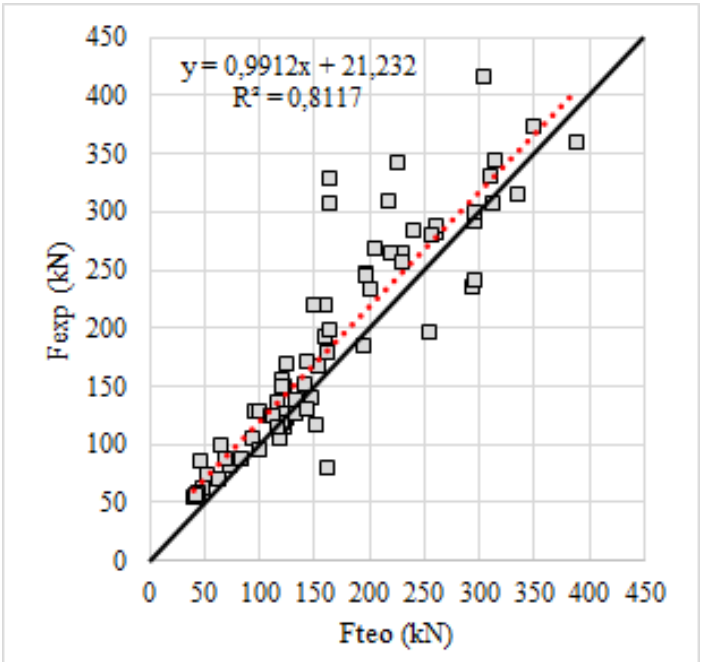

Figure A4. Accuracy of the Brazilian standard punching shear prediction model for border columns. 


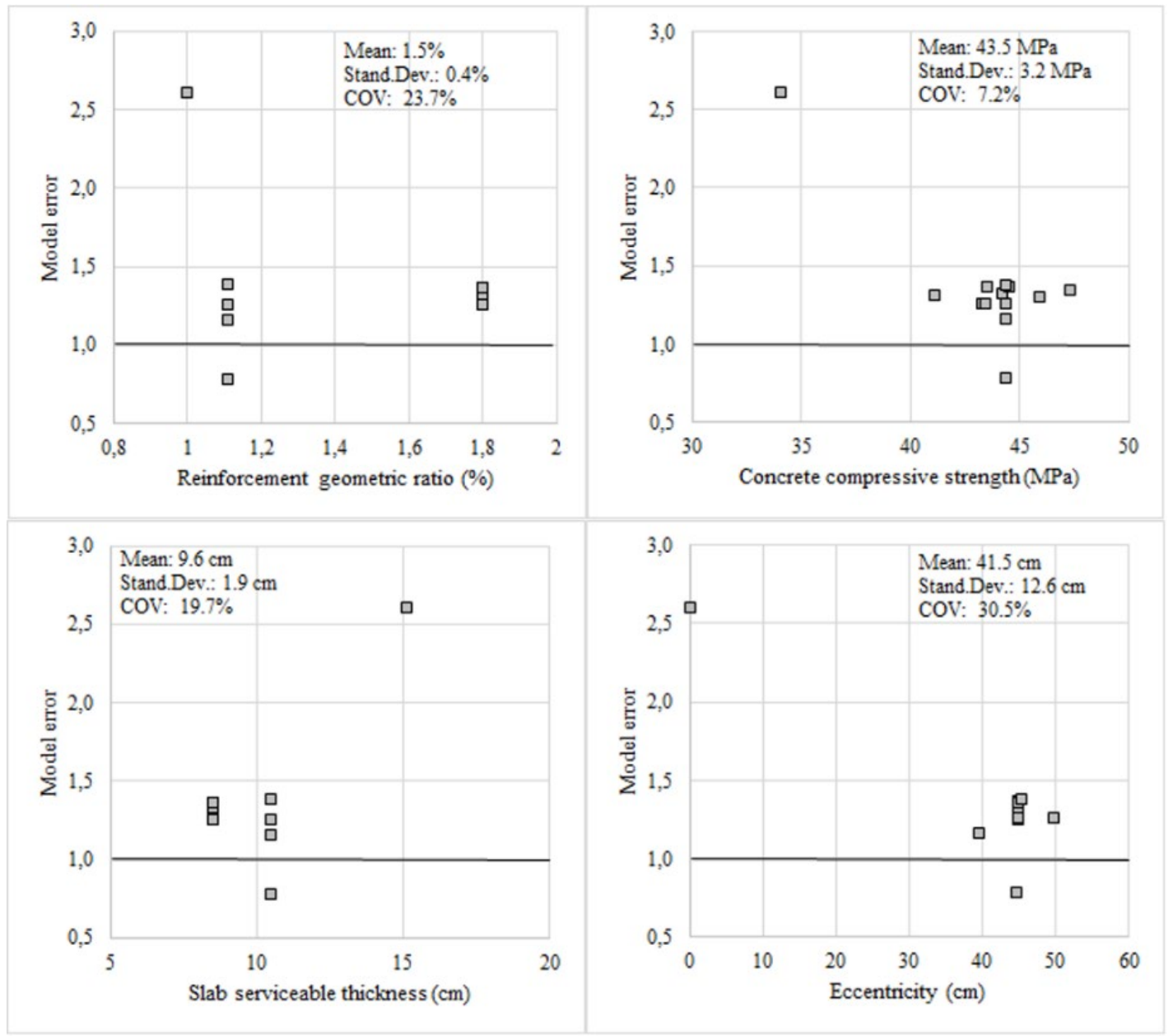

Figure A5. Influence of $\rho, f_{c}, d$ and $e$ on the model error for edge columns.

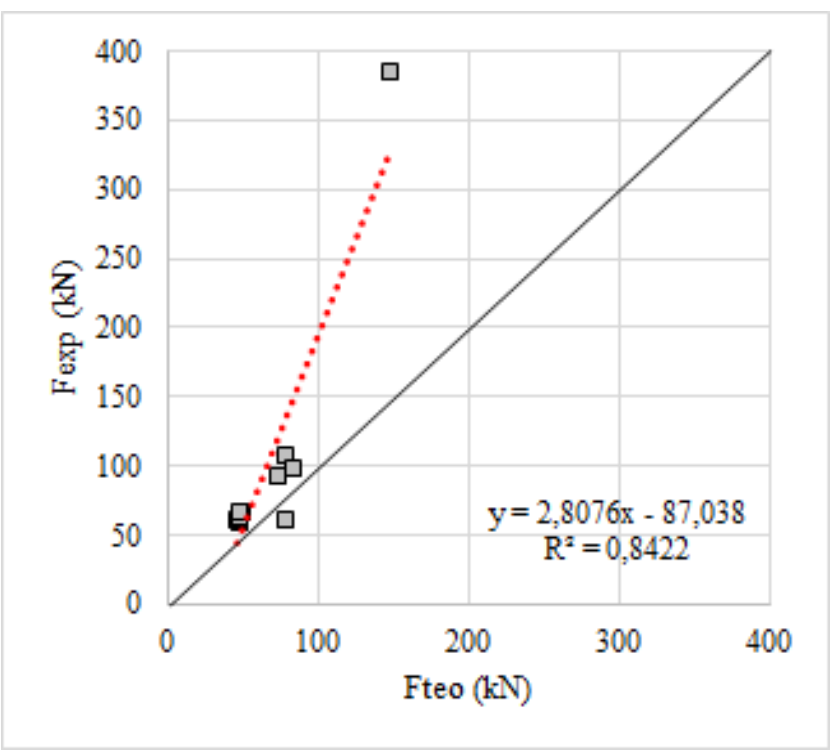

Figure A6. Accuracy of the Brazilian standard punching shear prediction model for edge columns. 